\title{
Cigarette Smoking and Electronic Cigarettes Use: A Meta-Analysis
}

\author{
Meng Wang ${ }^{1,+}{ }^{\dagger}$ Jian-Wei Wang ${ }^{2,+}$, Shuang-Shuang Cao ${ }^{2}$, Hui-Qin Wang ${ }^{3}$ and Ru-Ying Hu ${ }^{1, *}$ \\ Received: 9 November 2015; Accepted: 6 January 2016; Published: 12 January 2016 \\ Academic Editor: Zubair Kabir \\ 1 Zhejiang Provincial Center for Disease Control and Prevention, 3399 Binsheng Road, \\ Hangzhou 310051, China; mwang@cdc.zj.cn \\ 2 Yidu Central Hospital of Weifang. 4138 Linglong Road, Qingzhou, 262500, Shandong Province, China; \\ wangjw8711@163.com (J.-W.W.); caoss1234@163.com (S.-S.C.) \\ 3 Department of Preventative Medicine, School of Medicine, Ningbo University, 818 Fenghua Road, \\ Ningbo 315211, Zhejiang Province, China; wanghuiqin1990121@163.com \\ * Correspondence: ryhu@cdc.zj.cn; Tel.: +86-0571-8711-5164; Fax: +86-571-8711-5163 \\ + These authors contributed equally to this work.
}

\begin{abstract}
Increasing evidence indicates that cigarette smoking is a strong predictor of electronic cigarettes (e-cigarettes) use, particularly in adolescents, yet the effects has not be systematically reviewed and quantified. Relevant studies were retrieved by searching three databases up to June 2015. The meta-analysis results were presented as pooled odds ratios (ORs) with $95 \%$ confidence intervals (CIs) calculated by a random-effects model. Current smokers were more likely to use e-cigarette currently (OR: 14.89, 95\% CI: 7.70-28.78) and the probability was greater in adolescents than in adults ( $39.13 \mathrm{vs} .7 .51)$. The probability of ever e-cigarettes use was significantly increased in smokers (OR: 14.67, 95\% CI: 11.04-19.49). Compared with ever smokers and adults, the probabilities were much greater in current smokers (16.10 vs. 9.47) and adolescents (15.19 vs. 14.30), respectively. Cigarette smoking increases the probability of e-cigarettes use, especially in current smokers and adolescents.
\end{abstract}

Keywords: cigarette smoking; electronic cigarette; meta-analysis

\section{Introduction}

Electronic cigarettes (e-cigarettes) are battery-operated devices that do not burn or use tobacco leaves but instead vaporize a solution the user then inhales [1]. Since they were invented in 2003, e-cigarettes have captured considerable attention with huge controversy. On the one hand, e-cigarettes are supported as safer than conventional cigarettes and effective as smoking cessation aids [2,3]. On the other hand, there are a host of concerns about the potential health problems [4-6] and some reports do not support their efficacy for smoking cessation $[7,8]$. While the issues of safety and efficacy for cessation are under heated debate, e-cigarettes have gained popularity among both adolescents and adults. During the period of 2011-2012, the lifetime e-cigarettes use prevalence in US adolescents doubled from $3.3 \%$ to $6.8 \%$, and the similar rising trend in e-cigarettes use also emerged in adults [9-11]. Additionally, findings from the International Tobacco Control (ITC) Surveys covering 10 countries further indicate that the use of e-cigarettes has increased substantially globally [12].

Various potential factors have been reported to be associated with e-cigarettes use, including gender [13,14], socio-economic status [14,15], parental or friends smoking [14-16], and e-cigarettes harm perception $[14,16]$ and, most importantly, the cigarette smoking status. Although e-cigarettes may be used as a gateway to cigarette smoking by non-smokers, considerable studies have revealed that most e-cigarettes users are or were cigarette smokers in both adolescents and adults $[10,13,17,18]$. 
The relevant literature is increasing rapidly, but to date the effect of cigarette smoking on e-cigarettes use has not be systematically reviewed and quantified. Therefore, we retrieve the available literature and conduct a meta-analysis to provide the summary estimates of the effects.

\section{Materials and Methods}

\subsection{Literature Search Strategy}

We performed comprehensive searches of three databases (PubMed, Springer Link, Elsevier) from 2003 to June, 2015 to identify epidemiological studies on the association between cigarette smoking and e-cigarettes use. There were no language restrictions in the procedure of literature search, but only English papers were included in the meta-analysis. Ever use of e-cigarette was defined as "I have tried one" or "I have tried one, but do not smoke one in the past month"; current use of e-cigarette was defined as "I have smoked one in the past month". Ever and current cigarette smoking followed the above definitions. Detailed definitions were shown in Table A2 in the Appendix. The main search terms included "electronic cigarette", "e-cigarette", "electronic nicotine delivery systems", "vaping", "vaper", "vapor", "smoking", "cigarette smoking", "tobacco smoking", and "tobacco use". Reference lists of retrieved literature were also screened. The current study was carried out followed the Meta-analysis of Observational Studies in Epidemiology (MOOSE) guidelines [19].

\subsection{Eligibility Criteria and Data Extraction}

We selected studies that: (1) reported the association between cigarette smoking and e-cigarettes use (2) provided the odds ratios (ORs) with 95\% confidence intervals (CIs) for highest vs. lowest status of cigarette smoking or raw data to calculate these. Eligibility of studies was assessed and relevant information was extracted from each eligible study independently by two authors. The information included author"s name, year of publication, data source, location where the study conducted, sample size, study type, smoking status classification, and variables adjusted. The quality of each eligible study was assessed by the 9-star Newcastle-Ottawa Scale [20], a validated technique for assessing the quality of observational studies.

\subsection{Statistical Analysis}

A random effects model was used to calculate the pooled ORs with $95 \%$ CIs for cigarette smoking. Heterogeneity between studies was assessed using Q-test and the $\mathrm{I}^{2}$ statistic [21]. To explore the possible sources of heterogeneity, subgroup analyses were conducted based on cigarette smoking (ever and current smoking) and age group [adolescents (mean age $<18$ years) and adults (mean age $\geqslant 18$ years)], respectively. However, owing to the lack of data, analysis on the effect of ever smoking on current e-cigarettes use was not feasible. To test robustness of the current meta-analysis results, sensitivity analyses were also performed with excluding outliers. Publication bias was assessed by Egger's regression asymmetry test [22] and Begg's rank correlation test [23] ( $p$ values $<0.05$ were considered statistically significant). All the statistical analyses were conducted with STATA Version 11 software (StataCorp LP: College Station, TX, USA).

\section{Results}

\subsection{Overview of Included Studies}

Figure 1 showed the detailed procedures of study selection for this meta-analysis. Among the 54 potentially eligible studies, 20 articles were excluded because they were reviews, studies on mechanism or published without English language. A further eight studies not providing or providing unsuitable ORs and CIs for meta-analysis were also excluded. The detailed information of studies was shown in the Appendix, Table A2. Briefly, we identified 26 studies published between 2011 and 2015 for this meta-analysis. Most of studies were from the USA and Europe. The majority of included studies 
adjusted potential confounders for the final estimates, except for only three studies $[11,24,25]$. In the publication of Barnett et al. [26], results were respectively shown for middle and high school students, and were treated as two independent studies. As with the publication of Barnett $e t$ al., different results in the publications of Camenga et al. [27], King et al. [28], Ramo et al. [25] and Moore et al. [24] were also included in the current meta-analysis as independent studies. The quality score of studies ranged from 3 stars to 8 stars according to the 9-star Newcastle-Ottawa Scale.

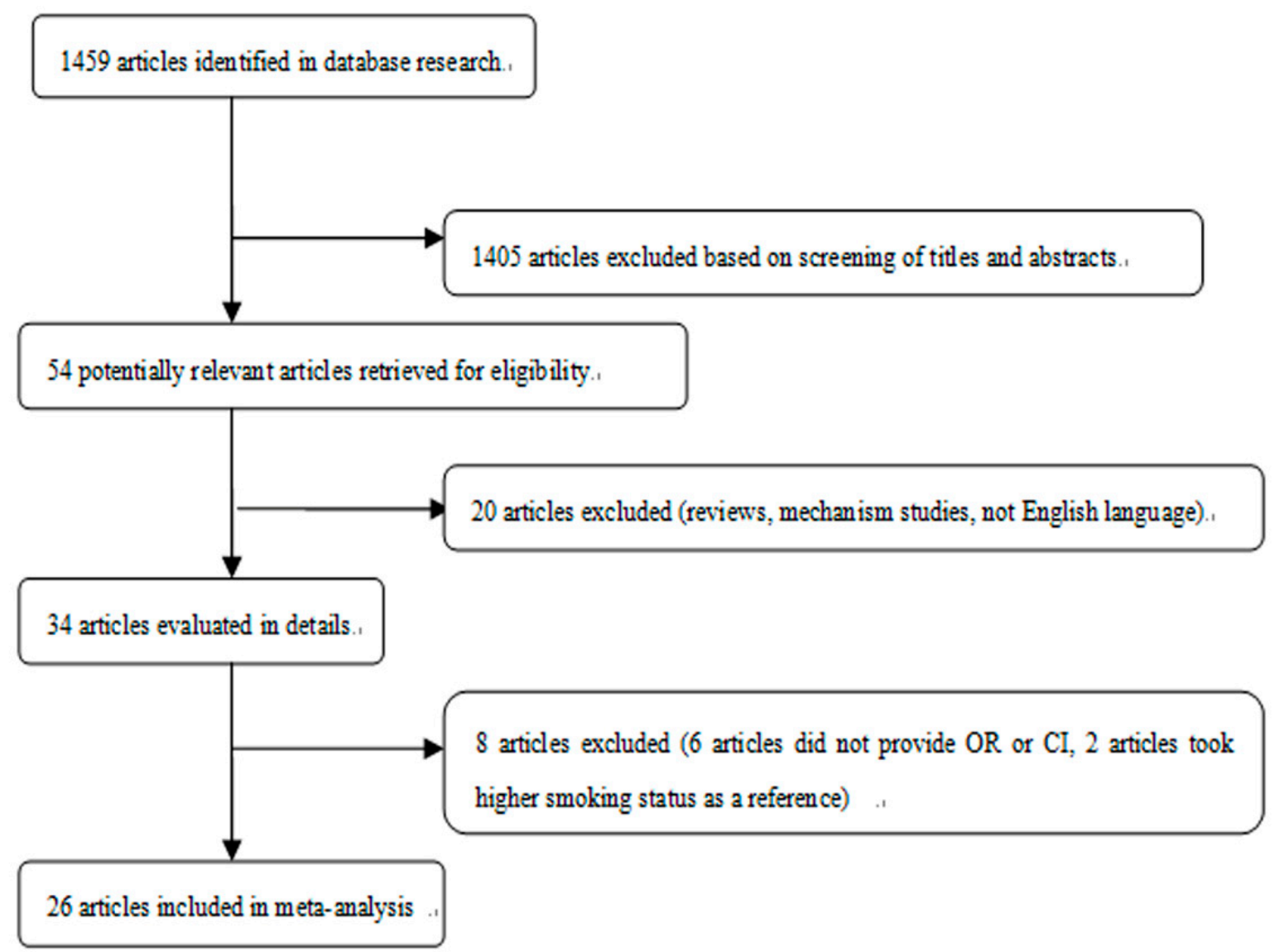

Figure 1. Study selection process.

\subsection{Meta-Analysis of Association between Current Smoking and Current E-Cigarettes Use}

The pooled analysis found that individuals with a status of current smoking had a great probability of current e-cigarettes use (OR $=14.89,95 \%$ CI: 7.70-28.78; Figure 2), although the formal test for heterogeneity gave a significant result $\left(\mathrm{I}^{2}=97.1 \%\right)$. Subgroup analysis based on age group was conducted and indicated that the effects of current smoking on current e-cigarettes use were greater in adolescents (OR $=39.13,95 \%$ CI: 22.11-69.26; Figure 2$)$ than in adults (OR $=7.51,95 \%$ CI: $3.68-15.35$; Figure 2). After excluding the outlier, the sensitivity analysis result of pooled OR was 13.27 (95\% CI: 6.71-26.24). 


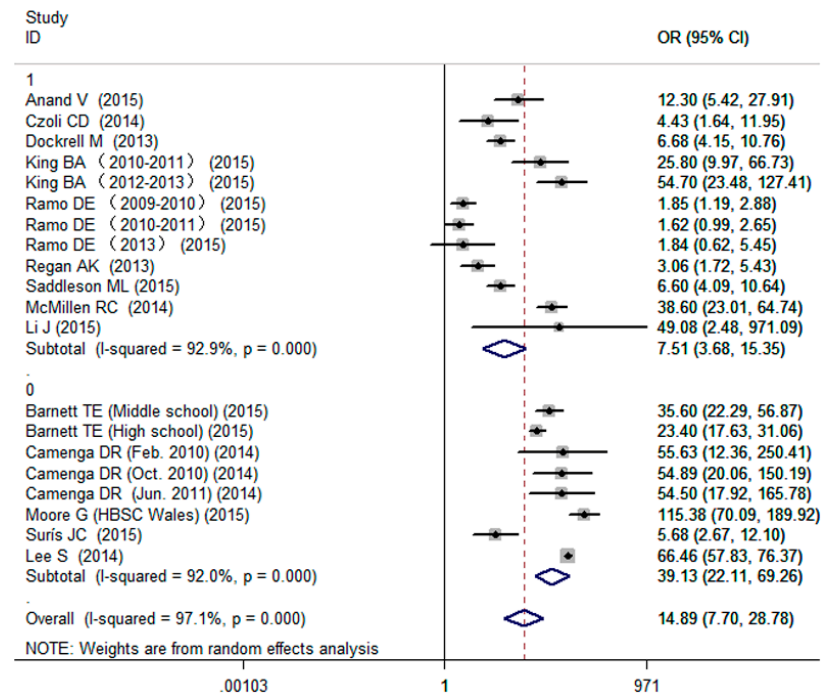

Figure 2. Effects of current smoking on current e-cigarettes use among adolescents and adults (0: adolescent 1: adult).

\subsection{Meta-Analysis of Association between Cigarette Smoking and Ever E-Cigarettes Use}

The results of meta-analysis showed that cigarette smoking was associated with increased probability of ever e-cigarettes use (OR $=14.67,95 \%$ CI: 11.04-19.49; Figure 3), with a high evidence of between-study heterogeneity $\left(\mathrm{I}^{2}=94.1 \%\right.$; Figure 3$)$. To further explore the possible sources of heterogeneity, subgroup analyses were conducted based on cigarette smoking status and age group. When subgroup analysis was conducted based on cigarette smoking status, we observed the pooled ORs were 16.10 (95\% CI: 11.68-22.19; Figure 3), 9.47 (95\% CI: 4.88-18.37; Figure 3) for the current smoking and ever smoking, respectively. When subgroup analysis was conducted based on age group, the pooled ORs were 14.30 (95\% CI: 9.99-20.47; Figure 4), 15.19 (95\% CI: 10.17-22.69; Figure 4) for the adults and adolescents, respectively. After excluding the outlier, the sensitivity analysis result of pooled OR was 13.84 (95\% CI: 10.41-18.40).

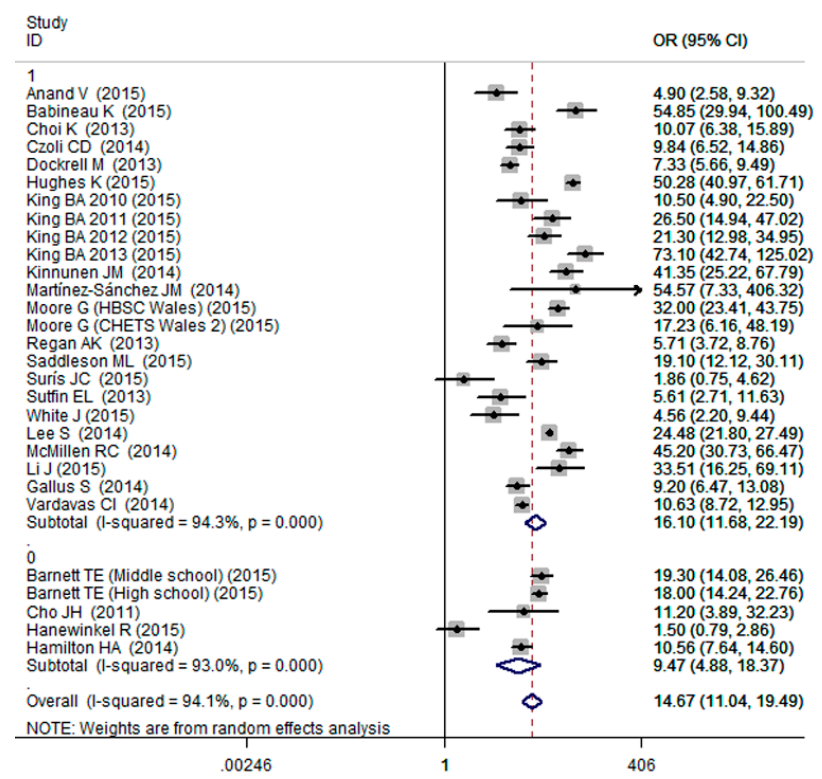

Figure 3. Effects of ever and current cigarette smoking on ever e-cigarettes use (0: ever smoking; 1: current smoking). 


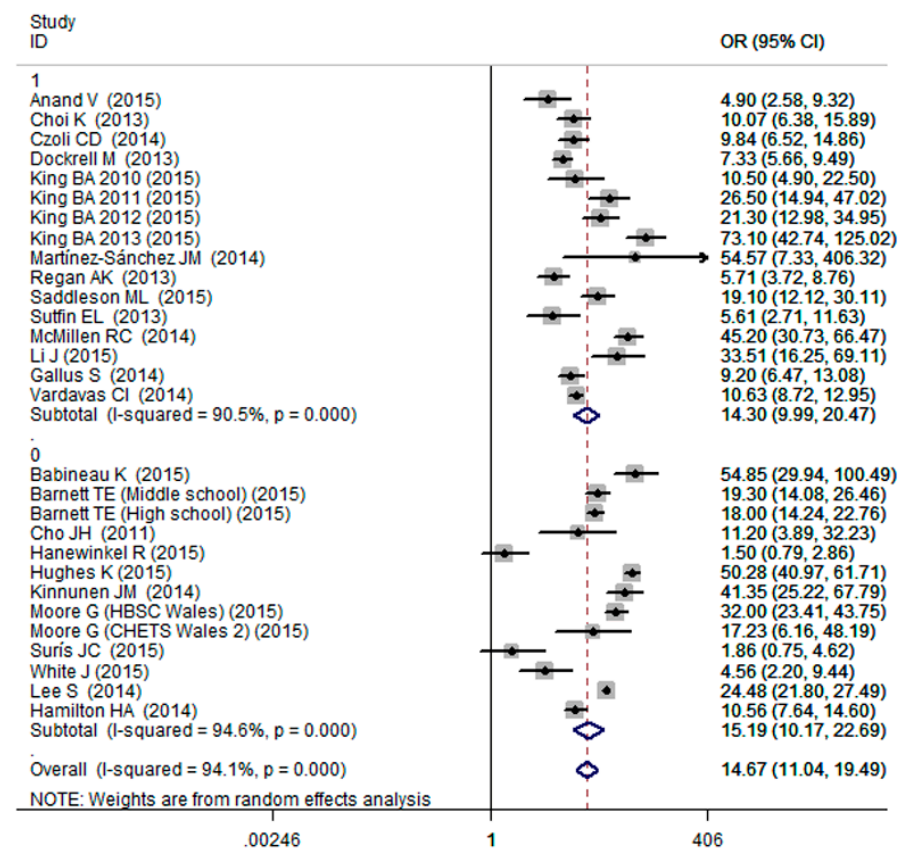

Figure 4. Effects of cigarette smoking on ever e-cigarettes use among adolescents and adults (0: adolescent; 1: adult).

\subsection{Publication Bias}

No evidence of publication bias was detected in the analysis of the associations between smoking and either current e-cigarettes use or ever e-cigarettes use (data not shown).

\section{Discussion}

This paper presents findings from the first meta-analysis to synthesize summary estimates of the effect of cigarette smoking on e-cigarettes use. Overall, our analysis results provided evidence that cigarette smoking, especially current smoking, was associated with great probability of current and ever e-cigarettes use. Recently, Wu et al. conducted a review on e-cigarettes prevalence and correlates of use, which came to the consistent conclusion that cigarette smoking was the only common correlate of e-cigarettes use in both adolescents and adults [18]. Furthermore, in the subgroup analyses, our observations suggested that the effect of cigarette smoking on e-cigarettes use was greater in adolescents than in adults. Similarly, Vardavas et al. performed a second analysis of Eurobarometer data of 26,566 youth and adults from 27 countries, with the finding that ever e-cigarettes use was more likely among younger current smokers [29]. Considering the facts that the safety information and the cessation properties of e-cigarettes are sparse and inconsistent, more solid public health evidence on e-cigarettes" long-term safety and smoking cessation efficacy are urgently needed.

Although the mechanisms by which cigarette smoking increased the probability of e-cigarettes use, especially in adolescents, were complicated, we advocated that smokers tend to accept e-cigarettes. First, previous study indicated that being a smoker was the strongest predictor of the willingness to try an e-cigarette [30]. Second, cigarette smokers were more likely to be susceptible to the e-cigarettes ads than non-smokers. Smith et al. conducted a web-based survey and the results indicated that exposure to e-cigarettes ads might enhance interest in e-cigarettes trial, particularly among cigarette smokers [31]. Since e-cigarettes were mostly advertised through the Internet, a study by Regan et al. further suggested that younger people were more exposed to e-cigarettes ads than older adults [11], which provided a possible interpretation of the greater effect of cigarette smoking on e-cigarettes use among adolescents. Additionally, according to previous literature, sensation seeking and the willingness to try new also contributed to the adolescent smokers" susceptibility to e-cigarettes use [18,30,32]. Third, e-cigarettes 
users generally perceived e-cigarettes were healthier than conventional cigarettes $[7,33,34]$ and studies suggested that those perceiving e-cigarettes as less harmful than cigarettes were more likely to use them $[7,16,29,35]$. To current and ever smokers, there was no exception. Evidence indicated that majority of cigarette smokers believed that e-cigarettes were safer than conventional cigarettes with the potential benefits for aiding to quit smoking [34,36,37].

The results from our meta-analysis study were subject to several limitations. One limitation was that high levels of heterogeneity were observed in the summary estimates, suggesting unexplained factors for variation still exist. As for the possible sources of heterogeneity, we attempted to speculate from the following aspects. First, most studies we assessed relied on the self-reported e-cigarettes use, which might underestimate the observed effects and contribute to the high levels of heterogeneity. Second, smaller estimates with narrow confidence interval were seen in studies conducted before 2013, while the effect seemed to be more pronounced with larger estimates in recent years of 2013 and 2014. Considering the e-cigarettes were newly sprouted things, which promoted and spread as aids for smoking cessation among smokers, we speculated that the year of the study explained part of heterogeneity. Third, different cultures, regulations on e-cigarettes, and source populations between the studies might be also responsible for the heterogeneity. Another limitation of our study was that most studies included in the current meta-analysis are cross-sectional studies, and we cannot identify the causality and rule out the residual confounding in some or all of the studies. Besides, most studies included in the meta-analysis defined "past 30-days use" as current use, which may include those who simply tried once in the last month.

\section{Conclusions}

In summary, this meta-analysis study indicates that cigarette smoking increases the probability of e-cigarettes use, especially in current smokers and adolescents. Given that our study is mostly based on cross-sectional studies, more evidence from longitudinal researches is needed.

Acknowledgments: The study was sponsored by “Clinical Medicine Research Special Fund of Chinese Medical Association" (Grant number: 13040530438).

Author Contributions: Meng Wang designed the study and collected, analyzed the data with Jian-Wei Wang, Shuang-Shuang Cao and Hui-Qin Wang. Ru-Ying Hu gave much advice and directions in both study design and preparing of the manuscript. All the authors have read and approved the final submitted version.

Conflicts of Interest: The authors declare no conflict of interest.

\section{Appendix}


Table A1. Definition of the e-cigarettes and cigarettes smoking status in studies included in the meta-analysis.

\begin{tabular}{|c|c|c|}
\hline Citation & The Definition of E-Cigarettes Use Status & The Definition of Cigarette Smoking Status \\
\hline Anand V, et al. 2015 [38] & $\begin{array}{l}\text { The life time use: have ever tried an e-cigarette. Current } \\
\text { use (Occasional use: at least one use occasion during the } \\
\text { past month. Regular use: at least } 10 \text { use occasions during } \\
\text { the past month. Daily use) }\end{array}$ & $\begin{array}{l}\text { 1. The life time use: have ever tried a cigarette. } \\
\text { 2. Current use (Occasional use: at least one use occasion during the past month. } \\
\text { Regular use: at least } 10 \text { use occasions during the past month Daily use) }\end{array}$ \\
\hline Babineau K, et al. 2015 [39] & Ever Users (those who had tried e-cigarettes) & $\begin{array}{l}\text { 1. Ever smoker: those who have tried smoking once or twice or have quit. } \\
\text { 2. Current smoker: those who smoke at least once a month }\end{array}$ \\
\hline Barnett TE, et al. 2015 [26] & $\begin{array}{l}\text { Ever user: "have you ever tried, even once" (yes). } \\
\text { Current user: "during the past } 30 \text { days, } \\
\text { have you used an e-cigarette" }\end{array}$ & $\begin{array}{l}\text { 1. "Ever cigarette use" was determined using the following question: Have you } \\
\text { ever tried cigarette smoking, even one or two puffs? If the respondents answered } \\
\text { yes they were categorized as an "ever cigarette user." } \\
\text { 2. "Current cigarette use" was determined using the following question: During the } \\
\text { past } 30 \text { days, on how many days did you smoke cigarettes? If the respondents } \\
\text { answered } 1 \text { or more, they were categorized as a "current cigarette user." }\end{array}$ \\
\hline Camenga DR, et al. 2014 [27] & $\begin{array}{l}\text { Past-30 day use of ENDS was measured by the response } \\
\text { to the question "In the PAST } 30 \text { DAYS, have you used any } \\
\text { of the following tobacco products?" } \\
\text { by selecting the option "E-cigarettes } \\
\text { (An electronic cigarette that is filled with liquid nicotine)". }\end{array}$ & Current smokers: In the PAST 30 DAYS, have you used tobacco? "Yes" \\
\hline Cho JH, et al. 2011 [40] & $\begin{array}{l}\text { "Have you ever smoked an e-cigarette, even one or two } \\
\text { puffs?" If they answered in the affirmative, they were } \\
\text { classified as having had the experience of e-cigarette use. }\end{array}$ & $\begin{array}{c}\text { Cigarette smoking experience: Have you ever smoked an e-cigarette, even one or } \\
\text { two puffs?" If they answered in the affirmative, they were classified } \\
\text { as having had the experience of e-cigarette use. }\end{array}$ \\
\hline Choi K, et al. 2013 [16] & $\begin{array}{l}\text { We asked those who were aware of e-cigarettes whether } \\
\text { they had ever used e-cigarettes (yes). }\end{array}$ & $\begin{array}{l}\text { 1. Former smoker: those who smoked } 100 \text { or over cigarettes } \\
\text { but had not smoked in the past } 30 \text { days. } \\
\text { 2. Current smoker: those who smoked } \\
100 \text { or over cigarettes and had smoked in the past } 30 \text { days. }\end{array}$ \\
\hline Czoli CD, et al. 2014 [41] & $\begin{array}{l}\text { e-cigarette "ever-users" had tried an e-cigarette, } \\
\text { but had not smoked one in the last } 30 \text { days; and "current } \\
\text { users" of e-cigarettes had tried an e-cigarette and } \\
\text { had smoked one in the last } 30 \text { days. }\end{array}$ & $\begin{array}{l}\text { 1. Former smokers: who had smoked } 100 \text { cigarettes } \\
\text { in their lifetime but had not smoked in the last } 30 \text { days. } \\
\text { 2. Current smokers were defined as those who had smoked } \\
100 \text { cigarettes in their lifetime and had smoked in the last } 30 \text { days; }\end{array}$ \\
\hline
\end{tabular}


Table A1. Cont.

\begin{tabular}{|c|c|c|}
\hline Citation & The Definition of E-Cigarettes Use Status & The Definition of Cigarette Smoking Status \\
\hline Dockrell M, et al. 2013 [36] & $\begin{array}{l}\text { Ever use: I have tried e-cigarettes in the past } 12 \text { months but do } \\
\text { not currently smoke them; I have tried e-cigarettes longer than } \\
12 \text { months ago but do not currently smoke them Current use: I } \\
\text { currently smoke e-cigarettes. }\end{array}$ & $\begin{array}{l}\text { Ex-smoker: I used to smoke but I have given up now. Occasional } \\
\text { smoker: I smoke but I don"t smoke every day; Daily smoker: I } \\
\text { smoke every day. }\end{array}$ \\
\hline Hanewinkel R, et al. 2015 [42] & $\begin{array}{c}\text { Lifetime use of e-cigarettes was assessed by asking “Have you } \\
\text { ever used an electronic cigarette?" (yes). }\end{array}$ & $\begin{array}{l}\text { Ever smoked a conventional cigarette: Students having smoked at } \\
\text { least a few puffs were considered as ever-smokers }\end{array}$ \\
\hline Hughes K, et al. 2015 [43] & $\begin{array}{l}\text { The question on e-cigarette access asked students "have you } \\
\text { ever tried or purchased e-cigarettes". }\end{array}$ & $\begin{array}{l}\text { 1. Ex-smokers were identified through the option "I used to smoke } \\
\text { but have given up" } 2 \text {. Those smoking less than } 5 \text { a day were } \\
\text { categorized as light regular smokers and those smoking at higher } \\
\text { levels as heavy regular smokers. }\end{array}$ \\
\hline King BA, et al. 2015 [28] & $\begin{array}{l}\text { Ever Use: ever use of e-cigarettes was assessed using the } \\
\text { question, "Have you ever tried any of the following products, } \\
\text { even just one time"? Respondents who selected "electronic } \\
\text { cigarettes or e-cigarettes" were considered to be ever e-cigarette } \\
\text { users. Current Use: current use of e-cigarettes was assessed by } \\
\text { the question, "In the past } 30 \text { days, which of the following } \\
\text { products have you used at least once"? Respondents who } \\
\text { selected "electronic cigarettes or e-cigarettes" were considered } \\
\text { to be current e-cigarette users. }\end{array}$ & $\begin{array}{l}\text { 1. Former smokers were respondents who smoked } 100 \text { or over } \\
\text { cigarettes in their lifetime and reported smoking "not at all" at the } \\
\text { time of survey. Current smokers were defined as respondents who } \\
\text { smoked } 100 \text { or over cigarettes in their lifetime and reported smoking } \\
\text { "everyday" or "some days" at the time of survey. }\end{array}$ \\
\hline Martínez-Sánchez JM, et al. 2014 [44] & $\begin{array}{c}\text { "Have you ever used e-cigarettes?" The answers to this } \\
\text { question were: "yes, currently"; "yes, in the past"; "I have only } \\
\text { experimented with e-cigarettes" }\end{array}$ & $\begin{array}{l}\text { 1. Former smokers as participant who did not smoke cigarettes at the } \\
\text { moment of the survey but had smoked cigarettes in the past. } 2 \text {. } \\
\text { Current smokers as participants who smoked cigarettes either daily } \\
\text { (at least one cigarette/day) or occasionally (less than one } \\
\text { cigarette/day) at the moment of the survey. }\end{array}$ \\
\hline Moore G, et al. 2015 [24] & $\begin{array}{l}\text { In CHETS Wales 2, children were asked if they had ever used } \\
\text { an e-cigarette, with response options of: "no"; "yes, once"; or } \\
\text { "yes more than once". In HBSC Wales, young people were } \\
\text { asked if they had ever used an e-cigarette, with response } \\
\text { options of: "I have never used or tried e-cigarettes"; “I have } \\
\text { used e-cigarettes on a few occasions (1-5 times)"; or "I } \\
\text { regularly use e-cigarettes (at least once a month)". }\end{array}$ & $\begin{array}{l}\text { Lifetime smoking was measured in CHETS Wales } 2 \text { by asking } \\
\text { children whether they ever smoked tobacco, with response options } \\
\text { of "yes" or "no". In the HBSC Wales survey, respondents were asked } \\
\text { "On how many days (if any) have you smoked cigarettes?", with } \\
\text { seven response options: "Never"; " } 1-2 \text { days"; " } 3-5 \text { days"; "6-9 }-9 \\
\text { days"; "10-19 days"; "20-29 days"; " } 30 \text { days or more". Respondents } \\
\text { who report "never" smoking cigarettes are compared to the other } \\
\text { response options to assess lifetime prevalence. In both surveys, } \\
\text { current smoking was assessed by asking "How often do you smoke } \\
\text { tobacco at present?" with response options of "every day", } \\
\text { "at least once a week, but not every day", } \\
\text { "less than once a week", and "I do not smoke". }\end{array}$ \\
\hline
\end{tabular}


Table A1. Cont.

\begin{tabular}{|c|c|c|}
\hline Citation & The Definition of E-Cigarettes Use Status & The Definition of Cigarette Smoking Status \\
\hline Ramo DE, et al. 2015 [25] & $\begin{array}{l}\text { Participants in all three studies were asked the same } \\
\text { question: "In the past month, have you used any } \\
\text { tobacco products other than cigarettes?" and given } \\
\text { ten answer choices, including } \\
\text { "e-cigarette/electronic cigarettes" and "other"; any } \\
\text { "other" answers that included electronic cigarettes } \\
\text { were recoded as such. }\end{array}$ & Daily smoker: smoked every day \\
\hline Regan AK, et al. 2013 [11] & $\begin{array}{l}\text { "Have you ever tried any of the following products, } \\
\text { even just one time, including e-cigarette. "In the } \\
\text { past } 30 \text { days, which of the following products have } \\
\text { you used at least once", including e-cigarette. }\end{array}$ & $\begin{array}{l}\text { 1. Former smokers had smoked } 100 \text { or over cigarettes in their } \\
\text { lifetime but currently do not smoke at all. } 2 \text {. Current smokers were } \\
\text { defined as adults who reported smoking } 100 \text { or over cigarettes in } \\
\text { their lifetime and currently smoke everyday or some days. }\end{array}$ \\
\hline Saddleson ML, et al. 2015 [45] & $\begin{array}{l}\text { E-cigarette ever use assessed by " Have you ever } \\
\text { tried or experimented with an e-cigarette, even one } \\
\text { or two puffs? " Those who responded "yes" were } \\
\text { classified as ever users. Current use included use } \\
\text { one or more days in the previous } 30 \text { days. }\end{array}$ & $\begin{array}{l}\text { 1. Former smokers (smoked } \geqslant 100 \text { cigarettes in lifetime, and have } \\
\text { smoked } 0 \text { out of the past } 30 \text { days); } 2 \text {. Experimenters (have ever tried } \\
\text { a cigarette, have smoked }<100 \text { cigarettes in lifetime, and have } \\
\text { smoked } 0 \text { of the past } 30 \text { days); } 3 \text {. Current smokers (have smoked at } \\
\text { least } 1 \text { day out of the past } 30 \text { ). For the multivariable analyses, } \\
\text { smoking status was collapsed into three categories (never smokers, } \\
\text { experimenters and ever [current and former smokers]), due to few } \\
\text { former smokers in our sample }(n=17) \text {. }\end{array}$ \\
\hline Surís JC, et al. 2015 [46] & $\begin{array}{l}\text { Experimenter: only once, } \\
\text { user: several time or regularly }\end{array}$ & A current smoker was defined as smoking at least weekly. \\
\hline Sutfin EL, et al. 2013 [47] & $\begin{array}{l}\text { Ever e-cigarette users were characterized as those } \\
\text { who responded yes. Current e-cigarette users were } \\
\text { a subset of ever users who reported smoking an } \\
\text { e-cigarette in the past month. }\end{array}$ & $\begin{array}{l}\text { 1. Former smoker or experimenter (smoked a whole cigarette in } \\
\text { lifetime, but not in the past } 30 \text { days); } 2 \text {. Current nondaily (smoked on } \\
\text { between } 1 \text { and } 29 \text { of the past } 30 \text { days); } 3 \text {. Current daily smoker } \\
\text { (smoked on all of the past } 30 \text { days) }\end{array}$ \\
\hline White J, et al. 2015 [48] & $\begin{array}{l}\text { "Have you ever tried electronic cigarettes?" } \\
\text { Those who answered "yes" were classified as } \\
\text { "e-cigarette ever-users." }\end{array}$ & $\begin{array}{l}\text { 1. Ex-smokers had smoked a cigarette but no longer smoked; } \\
\text { 2. Infrequent smokers smoked less often than once a month; } \\
\text { 3. Current smokers were those who reported smoking } \\
\text { at least once a month or more often. }\end{array}$ \\
\hline Lee S, et al. 2014 [49] & $\begin{array}{l}\text { E-cigarette use questions were: "Have you ever } \\
\text { used e-cigarettes?" (yes) and "Have you used } \\
\text { e-cigarettes in the past } 30 \text { days?" (yes). }\end{array}$ & $\begin{array}{l}\text { 1. Former smoker was defined as a respondent who had ever } \\
\text { smoked one puff, but had not smoked in the past } 30 \text { days. Current } \\
\text { smoker: at least one day smoked, even one puff, in the past } 30 \text { days. }\end{array}$ \\
\hline
\end{tabular}


Table A1. Cont.

\section{Citation}

McMillen RC, et al. 2014 [50]

Ever use; "Have you tried Electronic Cigarettes or

E-cigarettes, even just one time?" Current use:

Respondents who reported every day or some days.

Ever use: "Have you ever tried an electronic cigarette?" (yes) Current use: monthly use

Li J, et al. 2015 [51]

Ever smoker: have heard

and have tried e-cigarettes.

Gallus S, et al. 2014 [52]
The Definition of Cigarette Smoking Status

Respondents were asked, "Have you smoked at least 100 cigarettes in your entire life?" Respondents who reported that they had were then asked, "Do you now smoke cigarettes every day, some days, or not at all?" Respondents who reported that they have smoked at least 100 cigarettes and now smoke every day or some days were categorized as current smokers, while those who reported not at all were categorized as former smokers.

Former smoker: Have you ever tried a cigarette (yes); current smoker: at least monthly use

Ever smokers (current and ex-smokers) were participants

smoked 100 or mod participants who had quit smoking since at least 1 year; 2 . Current smokers were individuals continuing smoking or having stopped since less than 1 year.

(a)"never had a cigarette, not even one puff, in my life";

(b) "smoked from a few puffs to a whole cigarette in my life";

(c) "only 2-3 cigarettes in my life"; (d) "more than 3, but fewer than 100 cigarettes in my life"; (e) "100 or more cigarettes in my life, but none in the last month"; (f) "100 or more cigarettes in my life and some during the last month, but not every day"; and (g) "100 or more cigarettes in my life and at least 1 cigarette every day during the last month." For purposes of this analysis, a

dichotomous measure was constructed by combining Categories 2 through 7 to reflect ever smoked at least a puff of a cigarette (coded 1) versus never smoked (coded 0 ).

Ever use of an e-cigarette was self-reported and was assessed with the question "Have you ever tried (electronic cigarettes)?" Responses of "regularly", "occasionally", or "tried it once or twice" were categorized as having ever tried an e-cigarette.
Smokers: self-reported of current smoke status and chose the option of current smoker.
Vardavas CI, et al. 2014 [29]
"Have you ever smoked at least one puff from an electronic cigarette?" (yes) 
Table A2. Information of the studies included in the mata-analysis.

\begin{tabular}{|c|c|c|c|c|c|c|}
\hline Citation & Data Source & Location & Sample Size & Study Type & $\begin{array}{l}\text { Smoking Status } \\
\text { Classification }\end{array}$ & Variables Adjusted \\
\hline $\begin{array}{l}\text { Anand V, et al. } \\
2015[38]\end{array}$ & $\begin{array}{l}\text { Survey at school } \\
\text { of military } \\
\text { paramedical personnel }\end{array}$ & France & $\begin{array}{l}200 \text { students and } \\
\text { instructors aged } 18 \\
\text { years or over }\end{array}$ & Cross-sectional & $\begin{array}{l}\text { Tobacco current use } \\
\quad \text { (yes or no) }\end{array}$ & Gender and age \\
\hline $\begin{array}{l}\text { Babineau K, et al. } \\
2015[39]\end{array}$ & $\begin{array}{c}\text { Survey at } \\
\text { secondary schools }\end{array}$ & Ireland & $\begin{array}{l}821 \text { young people } \\
\text { aged } 16-17 \text { years }\end{array}$ & Cross-sectional & $\begin{array}{l}\text { Current tobacco user } \\
\text { (yes or no) }\end{array}$ & $\begin{array}{c}\text { Gender, school-level, } \\
\text { socioeconomic status, birth region }\end{array}$ \\
\hline $\begin{array}{l}\text { Barnett TE, et al. } \\
\quad 2015[26]\end{array}$ & $\begin{array}{l}2013 \text { Florida Youth } \\
\text { Tobacco Survey } \\
\text { (FYTS) }\end{array}$ & Florida & $\begin{array}{l}6440 \text { middle and } 6175 \\
\text { high school students }\end{array}$ & Cross-sectional & $\begin{array}{l}\text { Ever used cigarettes } \\
\text { (yes or no); Currently } \\
\text { use cigarettes } \\
\text { (yes or no) }\end{array}$ & $\begin{array}{l}\text { Gender, race, grade level, } \\
\text { other tobacco use }\end{array}$ \\
\hline $\begin{array}{l}\text { Camenga DR, et al. } \\
2014 \text { [27] }\end{array}$ & $\begin{array}{l}\text { Survey at two } \\
\text { suburban high } \\
\text { schools, 2010-2011 }\end{array}$ & $\begin{array}{l}\text { Connecticut \& } \\
\text { New York }\end{array}$ & $\begin{array}{l}\text { Wave } 1-1719 \text { Wave } \\
2-1702 \text { Wave } 3-1345, \\
\text { students in } \\
\text { grades } 9-12\end{array}$ & Cross-sectional & $\begin{array}{l}\text { Non-smoker; } \\
\text { Current smokers }\end{array}$ & $\begin{array}{l}\text { Study wave, school region, } \\
\text { grade, race, gender }\end{array}$ \\
\hline $\begin{array}{l}\text { Cho JH, et al. } \\
2011[40]\end{array}$ & $\begin{array}{l}2008 \text { Health } \\
\text { Promotion Fund } \\
\text { Project }\end{array}$ & Korea & 4341 students & Cross-sectional & $\begin{array}{c}\text { Cigarette smoking } \\
\text { experience } \\
\text { (never or ever) }\end{array}$ & $\begin{array}{l}\text { Gender, level of school, cigarette } \\
\text { smoking family, propensity to be } \\
\text { easily affected by friends, school life }\end{array}$ \\
\hline Choi K, et al. 2013 [16] & $\begin{array}{c}\text { Minnesota } \\
\text { Adolescent } \\
\text { Community Cohort }\end{array}$ & Minnesota & $\begin{array}{l}2624 \text { adults aged } \\
20-28 \text { years }\end{array}$ & $\begin{array}{l}\text { Cross-sectional from a } \\
\text { cohort study }\end{array}$ & $\begin{array}{l}\text { Never established } \\
\text { smoker; } \\
\text { Former smoker; } \\
\text { Current smoker } \\
\end{array}$ & $\begin{array}{l}\text { Age, gender, race, education, peer } \\
\text { smoking, perceptions of } \\
\text { electronic cigarettes }\end{array}$ \\
\hline $\begin{array}{l}\text { Czoli CD, et al. } \\
\quad 2014[41]\end{array}$ & $\begin{array}{l}\text { Survey at an online } \\
\text { panel of Canadians }\end{array}$ & Canada & $\begin{array}{l}1188 \text { youth and } \\
\text { young adults aged } \\
16-30 \text { years }\end{array}$ & Cross-sectional & $\begin{array}{l}\text { Non-smoker; } \\
\text { Former smoker; } \\
\text { Current smokers }\end{array}$ & Age, gender, race, education \\
\hline $\begin{array}{l}\text { Dockrell M, et al. } \\
\quad 2013[36]\end{array}$ & $\begin{array}{l}\text { Population surveys in } \\
2010 \& 2012\end{array}$ & Great Britain & $\begin{array}{c}2010-12,597(2297 \\
\text { smokers); } 2012-12,432 \\
\text { (2093 smokers) }\end{array}$ & Cross-sectional & $\begin{array}{l}\text { Ex-smoker; } \\
\text { Occasional smoker; } \\
\text { Daily smoker }\end{array}$ & Age, gender, social grade \\
\hline $\begin{array}{l}\text { Hanewinkel R, et al. } \\
2015 \text { [42] }\end{array}$ & $\begin{array}{l}\text { Survey at } 45 \text { public } \\
\text { secondary schools }\end{array}$ & Germany & $\begin{array}{l}2693 \text { adolescents } \\
\text { aged } 11-15 \text { years }\end{array}$ & $\begin{array}{l}\text { Cross-sectional from a } \\
\text { cohort study }\end{array}$ & $\begin{array}{l}\text { Ever smoked a } \\
\text { conventional cigarette } \\
\text { (yes or no) }\end{array}$ & $\begin{array}{l}\text { Gender, age, sensation seeking, } \\
\text { migration background, family } \\
\text { affluence, friend, sibling, parents } \\
\text { smoking, at a gymnasium, } \\
\text { experimental condition }\end{array}$ \\
\hline $\begin{array}{l}\text { Hughes K, et al. } \\
2015[43]\end{array}$ & $\begin{array}{l}\text { 5th iteration of the } \\
\text { Trading Standards } \\
\text { North West Alcohol } \\
\text { and Tobacco Survey }\end{array}$ & $\begin{array}{l}\text { North West } \\
\text { England }\end{array}$ & $\begin{array}{l}\text { 16,193 school students } \\
\text { aged } 14-17 \text { years }\end{array}$ & Cross-sectional & $\begin{array}{l}\text { Never smoked; Tried } \\
\text { but didn't like it; } \\
\text { Ex-smoker; Smoke } \\
\text { when drinking; } \\
\text { Regular light smoker; } \\
\text { Regular heavy smoker }\end{array}$ & $\begin{array}{c}\text { Gender, age, deprivation } \\
\text { parent/guardian smokes } \\
\text { drinking status }\end{array}$ \\
\hline
\end{tabular}


Table A2. Cont.

\begin{tabular}{|c|c|c|c|c|c|c|}
\hline Citation & Data Source & Location & Sample Size & Study Type & $\begin{array}{l}\text { Smoking Status } \\
\text { Classification }\end{array}$ & Variables Adjusted \\
\hline $\begin{array}{l}\text { King BA, et al. } \\
2015 \text { [28] }\end{array}$ & $\begin{array}{c}\text { 2010-2013 HealthStyles } \\
\text { Survey }\end{array}$ & USA & $\begin{array}{c}2010-25052011-4050 \\
2012-41702013-4033 \\
\text { Age: over } 18 \text { years }\end{array}$ & Cross-sectional & $\begin{array}{l}\text { Never smoker; Former } \\
\text { smoker; Current smoker }\end{array}$ & $\begin{array}{l}\text { Gender, age, race, education, } \\
\text { household income, region }\end{array}$ \\
\hline $\begin{array}{c}\text { Kinnunen JM, et al., } \\
2014[15]\end{array}$ & $\begin{array}{l}\text { Adolescent Health and } \\
\text { Lifestyle Survey }\end{array}$ & Finland & $\begin{array}{l}3535 \text { adolescents aged } \\
12-18 \text { years }\end{array}$ & Cross-sectional & $\begin{array}{l}\text { Never; Experimenter; Daily } \\
\text { smoker }\end{array}$ & $\begin{array}{l}\text { Age, gender, substance (snus / } \\
\text { waterpipe) use, parents" } \\
\text { smoking, seen e-cigarettes ads, } \\
\text { statement 'smoking is for loser", } \\
\text { school level, school performance, } \\
\text { family structure, father and } \\
\text { mother"s work situation. }\end{array}$ \\
\hline $\begin{array}{l}\text { Martínez-Sánchez JM, } \\
\text { et al. } 2014 \text { [44] }\end{array}$ & $\begin{array}{l}\text { Determinants of Cotinine } \\
\text { phase } 3 \text { project (dCOT3) }\end{array}$ & Barcelona & $\begin{array}{l}736 \text { adults aged } \\
16 \text { years or over }\end{array}$ & $\begin{array}{l}\text { Cross-sectional from a } \\
\text { cohort study }\end{array}$ & $\begin{array}{l}\text { Never smoker; Former } \\
\text { smoker; Current smoker }\end{array}$ & Gender, age, educational level \\
\hline $\begin{array}{l}\text { Moore G, et al. } \\
2015[24]\end{array}$ & $\begin{array}{l}\text { Child Exposure to Tobacco } \\
\text { Smoke (CHETS) survey } \\
\text { ('Wales 2"); Welsh Health } \\
\text { Behaviour in School-aged } \\
\text { Children (HBSC) Survey } \\
\text { ('HBSC Wales") }\end{array}$ & Wales & $\begin{array}{c}10,656 \text { students aged } \\
10-16 \text { years }\end{array}$ & Cross-sectional & $\begin{array}{l}\text { CHETS Wales 2: Ever } \\
\text { smoked cigarettes (yes or } \\
\text { no) Current tobacco use } \\
\text { (yes or no) HBSC Wales: } \\
\text { Ever smoked cigarettes (yes } \\
\text { or no) ; Frequency of } \\
\text { current tobacco use: I do } \\
\text { not smoke; Less than once } \\
\text { a week; At least once a } \\
\text { week (but not every day); } \\
\text { Every day }\end{array}$ & None \\
\hline $\begin{array}{l}\text { Ramo DE, et al. } \\
\quad 2015 \text { [25] }\end{array}$ & Online survey & USA & $\begin{array}{l}2661 \text { adults aged } \\
18-25 \text { years }\end{array}$ & Cross-sectional & Daily smoker (yes or no) & None \\
\hline $\begin{array}{l}\text { Regan AK, et al. } \\
2013[11]\end{array}$ & $\begin{array}{l}\text { ConsumerStyles survey } \\
2010\end{array}$ & USA & $\begin{array}{l}10,328 \text { adults aged } \\
18 \text { years or over }\end{array}$ & Cross-sectional & $\begin{array}{l}\text { Never smoker; Former } \\
\text { smoker; Current smoker }\end{array}$ & None \\
\hline $\begin{array}{l}\text { Saddleson ML, et al. } \\
2015 \text { [45] }\end{array}$ & Internet survey & Upstate New York & $\begin{array}{l}1437 \text { college students } \\
\text { aged } 18-23 \text { years }\end{array}$ & Cross-sectional & $\begin{array}{c}\text { Never-smoker; } \\
\text { Experimenter; Ever smoker }\end{array}$ & $\begin{array}{c}\text { Gender, race, age, institution, } \\
\text { school ability, other substance } \\
\text { use, such as marijuana, alcohol, } \\
\text { and belief that e-cigarettes are } \\
\text { less harmful than } \\
\text { tobacco cigarettes }\end{array}$ \\
\hline
\end{tabular}


Table A2. Cont.

\begin{tabular}{|c|c|c|c|c|c|c|}
\hline Citation & Data Source & Location & Sample Size & Study Type & $\begin{array}{l}\text { Smoking Status } \\
\text { Classification }\end{array}$ & Variables Adjusted \\
\hline $\begin{array}{l}\text { Surís JC, et al. } \\
2015 \text { [46] }\end{array}$ & $\begin{array}{l}\text { ado @ internet.ch } \\
\text { study }\end{array}$ & Switzerland & $\begin{array}{l}621 \text { youths with mean } \\
\text { age of } 16.2 \text { years }\end{array}$ & $\begin{array}{l}\text { Cross-sectional from a } \\
\text { longitudinal study }\end{array}$ & Current smoker (yes or no) & $\begin{array}{l}\text { Mean age, gender, academic } \\
\text { situation, substance use } \\
\text { (alcohol, cannabis) and } \\
\text { substance use (alcohol, } \\
\text { cannabis) at baseline aged } 14\end{array}$ \\
\hline $\begin{array}{l}\text { Sutfin EL, et al. } \\
2013 \text { [47] }\end{array}$ & $\begin{array}{l}\text { Web-based survey at } \\
8 \text { North Carolina } \\
\text { universities }\end{array}$ & North Carolina & $\begin{array}{l}4444 \text { students with } \\
\text { the average } \\
\text { age of } 20.5 \text { years }\end{array}$ & Cross-sectional & $\begin{array}{l}\text { Never smoked; Former } \\
\text { smoker; Current nondaily } \\
\text { smoker; Current } \\
\text { daily smoker }\end{array}$ & $\begin{array}{l}\text { Age, gender, race, greek off/on } \\
\text { campus residence, sensation } \\
\text { seeking, other substance use } \\
\text { (hookah, binge drinking, } \\
\text { marijuana, illegal drug), } \\
\text { e-cigarette harm perception }\end{array}$ \\
\hline $\begin{array}{l}\text { White J, et al. } \\
2015 \text { [48] }\end{array}$ & $\begin{array}{l}\text { Youth Insights Survey } \\
\text { (YIS) } 2014\end{array}$ & New Zealand & $\begin{array}{l}2919 \text { students } \\
\text { aged } 14-15 \text { years }\end{array}$ & Cross-sectional & $\begin{array}{l}\text { Nonsusceptible } \\
\text { never-smoker; Susceptible } \\
\text { never-smoker; Ex-smoker; } \\
\text { Infrequent smoker; } \\
\text { Current smoker }\end{array}$ & $\begin{array}{l}\text { Gender, race, school decile } \\
\text { status, weekly income, parental } \\
\text { smoking status, close friends } \\
\text { smoking status, past month } \\
\text { use of other tobacco products, } \\
\text { marijuana, ever binge drinker. }\end{array}$ \\
\hline Lee S, et al. 2014 [49] & $\begin{array}{l}2011 \text { Korean Youth } \\
\text { Risk Behavior } \\
\text { Web-based Survey }\end{array}$ & Korea & $\begin{array}{l}75,643 \text { students } \\
\text { aged } 13-18 \text { years }\end{array}$ & Cross-sectional & $\begin{array}{l}\text { Never smoker; Former } \\
\text { smoker; Current smoker }\end{array}$ & $\begin{array}{l}\text { Gender, location, grade, weekly } \\
\text { allowance, attempted to quit, } \\
\text { smoking prevention program }\end{array}$ \\
\hline $\begin{array}{l}\text { McMillen RC, et al. } \\
2014[50]\end{array}$ & $\begin{array}{c}\text { Computer-assisted } \\
\text { telephone survey } \\
2013\end{array}$ & USA & $\begin{array}{l}3245 \text { adults aged } \\
18 \text { years or over }\end{array}$ & Cross-sectional & $\begin{array}{c}\text { Never-smokers; Former } \\
\text { smokers; Nondaily smokers; } \\
\text { Daily smokers }\end{array}$ & $\begin{array}{l}\text { Region, race, age, } \\
\text { gender, education }\end{array}$ \\
\hline Li J, et al. 2015 [51] & $\begin{array}{l}2014 \text { Health and } \\
\text { Lifestyles Survey } \\
\text { (HLS) }\end{array}$ & New Zealand & $\begin{array}{l}2594 \text { adults aged } \\
15 \text { years or over }\end{array}$ & Cross-sectional & $\begin{array}{l}\text { Never smokers; Ex-smokers; } \\
\text { Current smokers }\end{array}$ & $\begin{array}{c}\text { Gender, ethnicity, age, } \\
\text { neighbourhood deprivation }\end{array}$ \\
\hline $\begin{array}{l}\text { Gallus S, et al. } \\
2014 \text { [52] }\end{array}$ & $\begin{array}{l}\text { An Italy national } \\
\text { survey on smoking }\end{array}$ & Italy & $\begin{array}{l}3000 \text { individuals aged } \\
15 \text { years or over }\end{array}$ & Cross-sectional & $\begin{array}{l}\text { Never smokers; Ex-smokers; } \\
\text { Current smokers }\end{array}$ & $\begin{array}{l}\text { Gender, age, level of education, } \\
\text { and geographic area. }\end{array}$ \\
\hline $\begin{array}{l}\text { Hamilton HA, et al. } \\
2014[53]\end{array}$ & $\begin{array}{l}2013 \text { Ontario Student } \\
\text { Drug Use and Health } \\
\text { Survey Canada } \\
\text { (OSDUHS) }\end{array}$ & Canada & $\begin{array}{l}2892 \text { students aged } \\
19 \text { or younger }\end{array}$ & Cross-sectional & $\begin{array}{l}\text { Tobacco use, lifetime } \\
\text { (yes or no) }\end{array}$ & Gender, grade, race, urbanicity \\
\hline $\begin{array}{l}\text { Vardavas CI, et al. } \\
2014[29]\end{array}$ & $\begin{array}{l}\text { Special } \\
\text { Eurobarometer } \\
385(77.1)\end{array}$ & $\begin{array}{l}27 \text { countries in the } \\
\text { European Union }\end{array}$ & $\begin{array}{l}26,566 \text { youth and } \\
\text { adults aged } \\
15 \text { years or over }\end{array}$ & Cross-sectional & $\begin{array}{l}\text { Current smoking status: } \\
\text { Non-smoker and smoker }\end{array}$ & $\begin{array}{l}\text { Perceived harmfulness of } \\
\text { e-cigarettes, residence, EU } \\
\text { region, gender, age, } \\
\text { self-reported difficulty in } \\
\text { paying bills }\end{array}$ \\
\hline
\end{tabular}




\section{References}

1. World Health Organization (WHO). Electronic Cigarettes (E-Cigarettes) or Electronic Nicotine Delivery Systems. Available online: http://www.who.int/tobacco/communications/statements/eletronic_cigarettes/ en/ (accessed on 21 October 2015).

2. Goniewicz, M.L.; Knysak, J.; Gawron, M.; Kosmider, L.; Sobczak, A.; Kurek, J.; Prokopowicz, A.; Jablonska-Czapla, M.; Rosik-Dulewska, C.; Havel, C.; et al. Levels of selected carcinogens and toxicants in vapour from electronic cigarettes. Tob. Control 2014, 23, 133-139. [CrossRef] [PubMed]

3. Bullen, C.; Howe, C.; Laugesen, M.; McRobbie, H.; Parag, V.; Williman, J.; Walker, N. Electronic cigarettes for smoking cessation: A randomised controlled trial. Lancet 2013, 382, 1629-1637. [CrossRef]

4. Vardavas, C.I.; Anagnostopoulos, N.; Kougias, M.; Evangelopoulou, V.; Connolly, G.N.; Behrakis, P.K. Short-term pulmonary effects of using an electronic cigarette: Impact on respiratory flow resistance, impedance, and exhaled nitric oxide. Chest 2012, 141, 1400-1406. [CrossRef] [PubMed]

5. Czogala, J.; Goniewicz, M.L.; Fidelus, B.; Zielinska-Danch, W.; Travers, M.J.; Sobczak, A. Secondhand exposure to vapors from electronic cigarettes. Nicotine Tob. Res. 2014, 16, 655-662. [CrossRef] [PubMed]

6. Grana, R.; Benowitz, N.; Glantz, S.A. E-cigarettes: A scientific review. Circulation 2014, 129, $1972-1986$. [CrossRef] [PubMed]

7. Adkison, S.E.; O'Connor, R.J.; Bansal-Travers, M.; Hyland, A.; Borland, R.; Yong, H.H.; Cummings, K.M.; McNeill, A.; Thrasher, J.F.; Hammond, D.; et al. Electronic nicotine delivery systems: International tobacco control four-country survey. Am. J. Prev. Med. 2013, 44, 207-215. [CrossRef] [PubMed]

8. Manzoli, L.; Flacco, M.E.; Fiore, M.; la Vecchia, C.; Marzuillo, C.; Gualano, M.R.; Ligurori, G.; Cicolini, G.; Capasso, L.; D'Amario, C.; et al. Electronic Cigarettes Efficacy and Safety at 12 Months: Cohort Study. PLoS ONE 2015, 10, e0129443. [CrossRef] [PubMed]

9. Centers for Disease Control and Prevention (CDC). Tobacco product use among middle and high school students-United States, 2011 and 2012. MMWR Morb. Mortal. Wkly. Rep. 2013, 62, 893-897.

10. Pearson, J.L.; Richardson, A.; Niaura, R.S.; Vallone, D.M.; Abrams, D.B. E-Cigarette awareness, use, and harm perceptions in US adults. Am. J. Public Health 2012, 102, 1758-1766. [CrossRef] [PubMed]

11. Regan, A.K.; Promoff, G.; Dube, S.R.; Arrazola, R. Electronic nicotine delivery systems: Adult use and awareness of the "e-cigarette" in the USA. Tob. Control 2013, 22, 19-23. [CrossRef] [PubMed]

12. Gravely, S.; Fong, G.T.; Cummings, K.M.; Yan, M.; Quah, A.C.; Borland, R.; Yong, H.H.; Hitchman, S.C.; Mc Neill, A.; Hammond, D.; et al. Awareness, trial, and current use of electronic cigarettes in 10 countries: Findings from the ITC project. Int. J. Environ. Res. Public Health 2014, 11, 11691-11704. [CrossRef] [PubMed]

13. Goniewicz, M.L.; Zielinska-Danch, W. Electronic cigarette use among teenagers and young adults in Poland. Pediatrics 2012, 130, e879-e885. [CrossRef] [PubMed]

14. Lotrean, L.M. Use of electronic cigarettes among Romanian university students: A cross-sectional study. BMC Public Health 2015, 15. [CrossRef] [PubMed]

15. Kinnunen, J.M.; Ollila, H.; EI-Amin, S.E.; Pere, L.A.; Lindfors, P.L.; Rimpelä, A.H. Awareness and determinants of electronic cigarette use among Finnish adolescents in 2013: A population-based study. Tob. Control 2015, 24. [CrossRef] [PubMed]

16. Choi, K.; Forster, J. Characteristics associated with awareness, perceptions, and use of electronic nicotine delivery systems among young US Midwestern adults. Am. J. Public Health 2013, 103, 556-561. [CrossRef] [PubMed]

17. Pepper, J.K.; Brewer, N.T. Electronic nicotine delivery system (electronic cigarette) awareness, use, reactions and beliefs: A systematic review. Tob. Control 2014, 23, 375-384. [CrossRef] [PubMed]

18. Carroll Chapman, S.L.; Wu, L.T. E-cigarette prevalence and correlates of use among adolescents versus adults: A review and comparison. J. Psychiatr. Res. 2014, 54, 43-54. [CrossRef] [PubMed]

19. Stroup, D.F.; Berilin, J.A.; Morton, S.C.; Olkin, I.; Williamson, G.D.; Rennie, D.; Moher, D.; Becker, B.J.; Sipe, T.A.; Thacker, S.B. Meta-analysis of observational studies in epidemiology: A proposal for reporting. Meta-analysis of Observational Studies in Epidemiology (MOOSE) group. JAMA 2000, 283, 2008-2012. [CrossRef] [PubMed]

20. Wells, G.A.; Shea, B.; O'Connell, D.; Peterson, J.; Welch, V.; Losos, M.; Tugwell, P. The Newcastle-Ottawa Scale (NOS) for Assessing The Quality of Nonrandomised Studies in Meta-Analyses. Available online: http://www.ohri.ca/programs/clinical_epidemiology/oxford.asp (accessed on 21 October 2015). 
21. Higgins, J.P.; Thompson, S.G.; Deeks, J.J.; Altman, D.G. Measuring inconsistency in meta-analyses. BMJ 2013, 327, 557-560. [CrossRef] [PubMed]

22. Egger, M.; Davey Smith, G.; Schneider, M.; Minder, C. Bias in meta-analysis detected by a simple, graphical test. BMJ 1997, 315, 629-634. [CrossRef] [PubMed]

23. Begg, C.B.; Mazumdar, M. Operating characteristics of a rank correlation test for publication bias. Biometrics 1994, 50, 1088-1101. [CrossRef] [PubMed]

24. Moore, G.; Hewitt, G.; Evans, J.; Littlecott, H.J.; Holiday, J.; Ahmed, N.; Moore, L.; Murphy, S.; Fletcher, A. Electronic-cigarette use among young people in Wales: Evidence from two cross-sectional surveys. BMJ Open 2015, 5, e007072. [CrossRef] [PubMed]

25. Ramo, D.E.; Young-Wolff, K.C.; Prochaska, J.J. Prevalence and correlates of electronic-cigarette use in young adults: Findings from three studies over five years. Addict. Behav. 2015, 41, 142-147. [CrossRef] [PubMed]

26. Barnett, T.E.; Soule, E.K.; Forrest, J.R.; Porter, L.; Tomar, S.L. Adolescent Electronic Cigarette Use: Associations with Conventional Cigarette and Hookah Smoking. Am. J. Prev. Med. 2015, 49, 199-206. [CrossRef] [PubMed]

27. Camenga, D.R.; Delmerico, J.; Kong, G.; Cavallo, D.; Hyland, A.; Cummings, K.M.; Krishnan-Sarin, S. Trends in use of electronic nicotine delivery systems by adolescents. Addict. Behav. 2014, 39, 338-340. [CrossRef] [PubMed]

28. King, B.A.; Patel, R.; Nguyen, K.H.; Dube, S.R. Trends in awareness and use of electronic cigarettes among US adults, 2010-2013. Nicotine Tob. Res. 2015, 17, 219-227. [CrossRef] [PubMed]

29. Vardavas, C.I.; Filippidis, F.T.; Agaku, I.T. Determinants and prevalence of e-cigarette use throughout the European Union: A secondary analysis of 26,566 youth and adults from 27 countries. Tob. Control 2015, 24, 442-448. [CrossRef] [PubMed]

30. Pepper, J.K.; Reiter, P.L.; McRee, A.L.; Cameron, L.D.; Gilkey, M.B.; Brewer, N.T. Adolescent males' awareness of and willingness to try electronic cigarettes. J. Adolesc. Health 2013, 52, 144-150. [CrossRef] [PubMed]

31. Smith, D.M.; Bansal-Travers, M.; O'Connor, R.J.; Goniewicz, M.L.; Hyland, A. Associations between perceptions of e-cigarette advertising and interest in product trial amongst US adult smokers and non-smokers: Results from an internet-based pilot survey. Tob. Induc. Dis. 2015, 13. [CrossRef] [PubMed]

32. Frankenberger, K.D. Adolescent egocentrism: A comparison among adolescents and adults. J. Adolesc. 2000, 23, 343-354. [CrossRef] [PubMed]

33. Etter, J.F.; Bullen, C. Electronic cigarette: Users profile, utilization, satisfaction and perceived efficacy. Addition 2011, 106, 2017-2028. [CrossRef] [PubMed]

34. Ambrose, B.K.; Rostron, B.L.; Johnson, S.E.; Portnoy, D.B.; Apelberg, B.J.; Kaufman, A.R.; Choiniere, C.J. Perceptions of the relative harm of cigarettes and e-cigarettes among U.S. youth. Am. J. Prev. Med. 2014, 47, S53-S60. [CrossRef] [PubMed]

35. Twyman, L.; Bonevski, B.; Paul, C.; Bryant, J.; Gartner, C.; Guillaumier, A. Electronic Cigarettes: Awareness, Recent Use, and Attitudes within a Sample of Socioeconomically Disadvantaged Australian Smokers. Available online: http://ntr.oxfordjournals.org/content/early/2015/09/16/ntr.ntv183.abstract (accessed on 21 October 2015).

36. Dockrell, M.; Morrison, R.; Bauld, L.; McNeill, A. E-cigarettes: Prevalence and attitudes in Great Britain. Nicotine Tob. Res. 2013, 15, 1737-1744. [CrossRef] [PubMed]

37. Brown, J.; West, R.; Beard, E.; Michie, S.; Shahab, L.; McNeill, A. Prevalence and characteristics of e-cigarette users in Great Britain: Findings from a general population survey of smokers. Addict. Behav. 2014, 39, 1120-1125. [CrossRef] [PubMed]

38. Guillet, S.; Sicard, S.; Meynard, J.B.; Mayet, A. Electronic cigarette: Use and perceptions among French military nurses in 2013. Swiss Med. Wkly. 2015, 145. [CrossRef]

39. Babineau, K.; Taylor, K.; Clancy, L. Electronic Cigarette Use among Irish Youth: A Cross Sectional Study of Prevalence and Associated Factors. PLoS ONE 2015, 10, e0126419. [CrossRef] [PubMed]

40. Cho, J.H.; Shin, E.; Moon, S.S. Electronic-cigarette smoking experience among adolescents. J. Adolesc. Health 2011, 49, 542-546. [CrossRef] [PubMed]

41. Czoli, C.D.; Hammond, D.; White, C.M. Electronic cigarettes in Canada: prevalence of use and perceptions among youth and young adults. Can. J. Public Health 2014, 105, e97-e102. [PubMed]

42. Hanewinkel, R.; Isensee, B. Risk factors for e-cigarette, conventional cigarette, and dual use in German adolescents: a cohort study. Prev. Med. 2015, 74, 59-62. [CrossRef] [PubMed] 
43. Hughes, K.; Bellis, M.A.; Hardcastle, K.A.; McHale, P.; Bennett, A.; Ireland, R.; Pike, K. Associations between e-cigarette access and smoking and drinking behaviours in teenagers. BMC Public Health 2015, 15. [CrossRef] [PubMed]

44. Martínez-Sánchez, J.M.; Ballbè, M.; Fu, M.; Martín-Sánchez, J.C.; Saltó, E.; Gottlieb, M.; Daynard, R.; Connolly, G.N.; Fernández, E. Electronic cigarette use among adult population: A cross-sectional study in Barcelona, Spain (2013-2014). BMJ Open 2014, 4, e005894. [CrossRef] [PubMed]

45. Saddleson, M.L.; Kozlowski, L.T.; Giovino, G.A.; Hawk, L.W.; Murphy, J.M.; MacLean, M.G.; Goniewicz, M.L.; Homish, G.G.; Wrotniak, B.H.; Mahoney, M.C. Risky behaviors, e-cigarette use and susceptibility of use among college students. Drug Alcohol. Depend. 2015, 149, 25-30. [CrossRef] [PubMed]

46. Surís, J.C.; Berchtold, A.; Akre, C. Reasons to use e-cigarettes and associations with other substances among adolescents in Switzerland. Drug Alcohol. Depend. 2015, 153, 140-144. [CrossRef] [PubMed]

47. Sutfin, E.L.; McCoy, T.P.; Morrell, H.E.; Hoeppner, B.B.; Wolfson, M. Electronic cigarette use by college students. Drug Alcohol Depend. 2013, 131, 214-221. [CrossRef] [PubMed]

48. White, J.; Newcombe, R.; Walton, D. Tripling use of electronic cigarettes among New Zealand adolescents between 2012 and 2014. J. Adolesc. Health 2015, 56, 522-528. [CrossRef] [PubMed]

49. Lee, S.; Grana, R.A.; Glantz, S.A. Electronic cigarette use among Korean adolescents: A cross-sectional study of market penetration, dual use, and relationship to quit attempts and former smoking. J. Adolesc. Health 2014, 54, 684-690. [CrossRef] [PubMed]

50. McMillen, R.C.; Gottlieb, M.A.; Shaefer, R.M.; Winickoff, J.P.; Klein, J.D. Trends in Electronic Cigarette Use Among U.S. Adults: Use is Increasing in Both Smokers and Nonsmokers. Nicotine Tob. Res. 2015, 17, 1195-1202. [CrossRef] [PubMed]

51. Li, J.; Newcombe, R.; Walton, D. The prevalence, correlates and reasons for using electronic cigarettes among New Zealand adults. Addict. Behav. 2015, 45, 245-251. [CrossRef] [PubMed]

52. Gallus, S.; Lugo, A.; Pacifici, R.; Pichini, S.; Colombo, P.; Garattini, S.; la Vecchia, C. E-cigarette awareness, use, and harm perceptions in Italy: A national representative survey. Nicotine Tob. Res. 2014, 16, 1541-1548. [CrossRef] [PubMed]

53. Hamilton, H.A.; Ferrence, R.; Boak, A.; Schwartz, R.; Mann, R.E.; O'Connor, S.; Adlaf, E.M. Ever Use of Nicotine and Nonnicotine Electronic Cigarettes among High School Students in Ontario, Canada. Nicotine Tob. Res. 2015, 17, 1212-1218. [CrossRef] [PubMed]

(C) 2016 by the authors; licensee MDPI, Basel, Switzerland. This article is an open access article distributed under the terms and conditions of the Creative Commons by Attribution (CC-BY) license (http:/ / creativecommons.org/licenses/by/4.0/). 